Антоніна ВАРЛАКОВА, orcid.org/0000-0001-9781-9001 аспірант кафедри германської та фіно-угорської філологіі Київського начіонального лінгвістичного університету (Київ, Україна) antoninavarlakova@gmail.com

\title{
МЕТОДИКА ПРОВЕДЕННЯ ЕКСПЕРИМЕНТАЛЬНО-ФОНЕТИЧНОГО ДОСЛІДЖЕННЯ ПРОСОДИЧНИХ ОЗНАК НЕНАГОЛОШЕНОГО ВОКАЛІЗМУ В АНГЛІЙСЬКОМУ МОВЛЕННІ УКРАЇНЦІВ
}

\begin{abstract}
Темою статті є сучасні експериментальні методи фонетичних досліджень та їх застосування під час вивчення просодичних ознак ненаголошеного вокалізму в англійському мовленні українців. Для розкриття тематики викладено проблеми дослідження просодичних характеристик підготованого мовлення, а саме читання англійських художніх текстів, і варіювання ненаголошених голосних. Також серед проблем, описаних у публікаиії, використання методик для аналізу акустичних особливостей ненаголоменого вокалізму й співвіднесення їхніх модифікацій із відхиленнями в просодичному оформленні мовлення. Мета публікації полягає у викладенні комплексного підходу й комбінації об 'єктивних і суб 'єктивних методів у фонетичних дослідженнях для вивчення впливу сегментних порушень на просодичне оформлення усного мовлення. Дослідження просодичних ознак ненаголошеного вокалізму проводилося з метою виявлення специфічних характеристик інтерференції в англійському мовленні українців та ї̈ впливу на сприйняття та розуміння змісту. Методика проведення експериментально-фонетичного дослідження базувалася на системному підході до аналізу мовлення. 3 огляду на поставлені завдання, було обрано методи й створено програму дослідження. Таким чином, обрані методи експериментально-фонетичного дослідження дозволяють вивчити акустичні характеристики ненаголошених звуків, порівняти їх з еталоном для встановлення типових вимовних відхилень, виявити вплив відхилень на сегментному рівні на просодичне оформлення усного мовлення та встановити його зв'язок зі зрозумілістю та природністю звучання англійського мовлення украӥнців. Отримані під час експерименту дані про ймовірні модифікаційні процеси в системі ненаголошеного вокалізму, зміни просодичних характеристик мовлення дикторів дозволять визначити просодичні ознаки голосних у слабких позичіях.
\end{abstract}

Ключові слова: просодичні характеристики, усне мовлення, ненаголочений вокалізм, методи дослідження.

\author{
Antonina VARLAKOVA, \\ orcid.org/0000-0001-9781-9001 \\ Postgraduate Student at the Germanic and Finno-Ugric Philology Department \\ Kyiv National Linguistic University \\ (Kyiv, Ukraine) antoninavarlakova@gmail.com
}

\section{PHONETIC EXPERIMENTAL RESEARCH METHODS OF UNSTRESSED VOCALISM PROSODIC FEATURES IN ENGLISH SPEECH OF UKRAINIANS}

The topic of the article is the modern experimental methods of phonetic research and their application in the study of unstressed vocalism prosodic features o in the English speech of Ukrainians. For the development of the given subject matter, the problems of further prosodic characteristics development of the prepared speech are discussed, and the reading of English non-fiction texts itself, the variations of unstressed vowels. Also, one of the problems described in the publication, are methods for analyzing the acoustic features of unstressed vocalism and processing of changes in prosodic features of speech. The aim of the publication is to study a complex approach and a combination of subjective and objective methods in phonetic research for the influence of segmental deviations on prosodic features of the speech. The research of unstressed vocalism prosodic features was carried out on the basis of the appearance of the interference specific characteristics in the English speech of Ukrainians and its influence on the perception and understanding of content. The technique of carrying out the experimental phonetic research was based on the systemic approach to the speech analysis. Taking into account the tasks of the research, the methodology and the program of experiment was chosen. These methods of the research allow to study acoustic characteristics of unstressed vocalism, to compare them with the sounds produced by the native speaker for identifying types of speech deviations, their influence on prosodic features of the speech and their connection with clearness and naturalness of the English speech of Ukrainians. The received data of the experiment about the possible modifications in the system of unstressed vocalism, the changes of prosodic characteristics of speech, allow to define prosodic features of vowels in weak positions.

Key words: prosodic features, speech, unstressed vocalism, research methods 
Постановка проблеми. Проблематика застосування сучасних експериментальних методів дослідження зумовлена необхідністю отримання даних щодо характерних просодичних ознак ненаголошеного вокалізму й вимагає застосування як суб'єктивних, так і об'єктивних методів дослідження. Суб'єктивні методи дозволяють отримати дані про враження, зрозумілість і нормативність вимови. За допомогою об'єктивних методів дослідження отримані дані буде підтверджено вимірюваннями й підрахунками, що забезпечить певність результатів. Так, методологія сучасної експериментальної фонетики базується на поєднанні аудитивного й акустичного аналізів із залученням методів кількісної обробки отриманих даних (Кантер,1988: 7). Порівняння як одна зі стратегій дискурс-аналізу дозволяє встановити специфічні просодичні характеристики мовлення носіїв англійської мови й розкрити значення окремих просодичних параметрів для здійснення впливу на слухачів шляхом зіставлення вражень, отриманих реципієнтами від прослуховування текстів із різною просодичною організацією.

Аналіз досліджень. Засвідчує необхідність вивчення просодичних характеристик озвученої художньої прози, аудіокниги як її різновиду проведений нами аналіз сучасних досліджень. Сучасний британський вчений М. Рабері, вивчаючи історію розвитку й особливості озвученої художньої літератури, зазначає, що аудіокнига - це художня або освітня література, начитана й записана на електронний носій. Також його дослідження свідчать, що сприйняття змісту книги, прочитаної мовчки (“silent reading”), значно відрізняється від прослуховування озвученого тексту (Rubery, 2008: 58).

Проблематика дослідження особливостей усної реалізації художнього тексту стосується, зокрема, структурних типів і жанрів текстів. Водночас у залежності від типової та жанрової приналежності, ступеня динамічності й емоційно-прагматичного потенціалу звучання тексту набуває специфічних рис (Кожина, 2002: 202). Особливості просодичного оформлення художнього тексту досліджуються на тлі загальної моделі механізму їхної усної реалізації. Так, 3 одного боку, широко відомою в лінгвістиці $\epsilon$ модель мовленнєвої діяльності Ф. де Соссюра (Соссюр, 1977: 23), яка охоплює основні психічні, фізіологічні й фізичні процеси. 3 іншого боку, в моделі, запропонованій Р. Якобсоном, теорія комунікативних систем грунтується на проблематиці мови, культури й мистецтва (Якобсон, 1985: 27). Своєю чергою функціональноенергетична модель, розроблена А. А. Калитою, розглядає кожне висловлення або їх групу з боку актуалізації в них різного за ступенем емоційнопрагматичного потенціалу (Калита, 2000: 12).

Взявши за основу вище зазначені класичні моделі мовленнєвої діяльності, вітчизняні лінгвісти Ю. М. Скребнев і М. Д. Кузнец запропонували терміни «літературно-відпрацьований» і «вільний» стилі висловлювань. Театральне мовлення та озвучені художні тексти, очевидно, належать до літературно-відпрацьованого стилю, позаяк він реалізується не лише в публіцистичних, науково-професійних та офіційних текстах, а й у художній прозі. Літературно-відпрацьований стиль, на думку авторів, характеризується відповідністю всіх форм і норм національної літературної мови (Скребнев, 1960: 45).

Безумовно, важливим диференційним показником стильової приналежності $є$ інтонаційна структура мовлення. Слід також зазначити, що фоностилі не функціонують відокремлено від функціональних стилів. Під час стильової диференціації мовлення фонетичні засоби можуть виступати як основні, а можуть корелювати з лексико-граматичними засобами (Ахманова, 2005: 7).

Група факторів, що впливають на вибір стилю, виражає стратегію мовця та містить ціль висловлювання та тему. Кожен із варіантів передбачає вибір фонетичних засобів із метою здійснення ефективної комунікації. До факторів, що модифікують, належать такі екстралінгвістичні фактори, як ставлення мовця до ситуації спілкування, форма комунікації, ступінь формалізованості ситуації та дискурсу (Великая, 2008: 48).

Відомо, що всі вищезазначені фактори комунікативної ситуації, що беруть участь у формуванні фоностилю, корелюють із фонетичними характеристиками, які мають стилерозрізнювальну роль на рівні сприйняття тексту. Так, в I. В. Арнольд це висота тону, тривалість вимови, гучність, темп мовлення, паузи, емфатичні наголоси (Арнольд, 1973: 250). Своєю чергою М. А. Соколова відзначає делімітацію, акцентуацію смислових центрів i тональні зміни: тональний діапазон, рівень i напрям руху тону, гучність мовлення, темп, ритм, тембр та інші компоненти інтонації (Соколова, 2010: 29-30).

Мета статті - обгрунтувати й описати методику дослідження особливостей просодичного оформлення англійського мовлення українців шляхом виявлення характерних ознак ненаголошеного вокалізму в озвученому художньому тексті й розкриття ролі сегментних порушень для створення ритмічності мовлення та його просодичного оформлення. Гіпотеза грунтувалася на 
припущенні про те, що порушення просодії іншомовного мовлення спричиняється, серед іншого, одним із проявів фонетичної інтерференції, а саме відхиленнями в системі ненаголошеного англійського вокалізму, що спричиняє порушення форми й сприйняття змісту мовлення.

Виклад основного матеріалу. Методика проведення експериментально-фонетичного дослідження базувалася на системному підході до аналізу мовлення. Висока емоційність та експресивність, притаманні художньому стилю, стали підгрунтям для дослідження просодичних характеристик усної реалізації саме художньої прози.

Дослідження проводилося шляхом порівняння просодичного оформлення, структури й тривалості ритмогруп та акустичних характеристик ненаголошених голосних у текстах, начитаних дикторомносієм британського варіанту англійської мови, й тих самих текстах, озвучених аудиторами-інформантами, носіями української мови, котрі мають різний рівень опанування англійською мовою.

Комплексна методика вивчення звукової реалізації озвучених художніх прозових творів дає змогу отримати всебічну, об'єктивну інформацію про їх просодичне оформлення. Така методика передбачає: 1) підбір експериментального матеріалу; 2) аудитивний аналіз мовлення аудиторами-інформантами 3 філологічною підготовкою для 3'ясування супрасегментних системотвірних ознак вимовних відхилень в англійському мовленні українців; 3) установлення основних ознак просодичного оформлення інтерферованого мовлення українців за допомогою аудитивного аналізу аудиторами, зокрема виявлення таких характеристик англійського мовлення українців: зрозумілість, чіткість, темп, гучність мовлення, висота тону, кількість фразових наголосів; 4) акустичний аналіз просодичних характеристик усного мовлення та ненаголошених голосних, реалізованих дикторами для 3'ясування вимовних відхилень у системі ненаголошеного англійського вокалізму.

Підгрунтям для дослідження просодичних характеристик усної реалізації саме художньої прози стала іiі висока емоційність та експресивність для забезпечення досягнення основної мети. В основному, озвучені художні тексти мають на меті вплинути на думки й почуття слухачів, що зумовлює використання широкого спектра інтонаційних структур і просодичних засобів (гучності, темпу, тонального діапазону), які під час звертання до слухачів і справляють емоційний вплив.

Відповідно до мети й завдань дослідження проводилося на матеріалі озвучених оповідань (аудіокниги) британської письменниці-модер- ністки першої половини XX століття Вірджинії Вулф. Короткі оповідання дали змогу опрацювати тексти 3 різним змістом і лексичним наповненням, граматичним і синтаксичним оформленням, настроєм та емоційним забарвленням. Ранні оповідання Вірджинії Вулф не перевантажені глибоким змістом і складними світоглядними питаннями, більше описуючи психологічні стани, відчуття та мислення героїв. Відмова від хронології, фрагментарність у зображенні подій, образність мислення також характерні для іiї оповідань. Автор намагалася мовними засобами передати не лише самі думки, а й зробити акцент на процесі мислення та душевних пошуках. Таким чином, за допомогою частих повторів слів, фраз, реплік і речень Вулф привертає увагу читача до головної теми оповідань, до основної мети пошуку персонажів, причини їх переживань і роздумів. Повторювані елементи, являючись ядром кожного абзацу оповідання, несуть емфатичний наголос і слугують його наголошеним центром та основою ритму твору.

На відміну від емфатично маркованих одиниць, службові слова частіше за все вживаються у зв'язному мовленні в слабких формах, із заміною повнозвучних голосних на редукований нейтральний голосний (Crystal, 1999: 248).

Вивчаючи просодичну організацію озвучених англійських оповідань, необхідно враховувати той факт, що ритм не $є$ ознакою лише озвученого тексту, він притаманний мові загалом, а отже, певна ритміка закладена вже в письмовій формі тексту й визначена лексичним наповненням фраз і синтаксичною будовою речень. Проте доцільно припустити, що під час читання підготовленого тексту диктор концентрує свою увагу на лексично-граматичній організації тексту й орієнтується на пунктуаційну систему для сегментації тексту. Речення мають чітку ритмічну організацію завдяки рівномірним паузам i чергуванню наголошених $\mathrm{i}$ ненаголошених складів. Збільшення кількості наголосів у фразі сприяє збільшенню ритмогруп, що своєю чергою спричиняє порушення ритму й модифікацію якості ненаголошених голосних.

Таким чином, щоб виявити ступінь впливу фонетичних порушень сегментного рівня на просодичну організацію мовлення в цілому, проведено експеримент, спрямований на порівняння просодичного оформлення озвучених оповідань, начитаних носієм англійської мови й носіями української мови з різним рівнем володіння англійською.

Експериментальний матеріал, представлений у статті озвученими художніми текстами, сприятиме дослідженню не лише специфіки просодичної організації підготовленого англійського 
мовлення українців, а й визначенню модифікацій у системі ненаголошеного англійського вокалізму. Вивчення зазначеного типу усного мовлення уможливлює встановлення впливу різних чинників на функціонування ненаголошених голосних фонем у підготовленому мовленні дикторів-українців. Отримані під час експерименту дані про ймовірні модифікаційні процеси в системі ненаголошеного вокалізму, зміни просодичних характеристик мовлення дикторів дозволять визначити просодичні ознаки голосних у слабких позиціях.

Аудіозаписи оповідань, відібрані нами для аналізу, записані англомовною жінкою-диктором у 2011 році для інтернет-ресурсу аудіокниг LibriVox. Оповідання було записано у форматах MP3 та MP4 і конвертовано у звукові файли 3 розширенням wav за допомогою програм Switch Sound File Converter.

Загальний корпус експериментального матеріалу склали 6 озвучених оповідань зі збірок британської письменниці Вірджинії Вулф тривалістю звучання 40 хвилин.

Для реалізації експерименту було створено 4 відносно гомогенні за віком групи дикторів. Відібрані групи відрізнялися за рівнем володіння та досвідом спілкування англійською мовою.

На першому етапі експерименту дикторам було запропоновано прочитати 6 оповідань Вірджинії Вулф у голос, із попередженням, що їх буде записано на електронний носій. Також запису текстів передувала бесіда 3 дикторами, під час якої пояснювалися задачі експерименту, обговорювалися жанрові й фоностилістичні особливості художнього тексту, оскільки важливо було переконатися, що диктори розуміють жанр і тип тексту, котрий необхідно озвучити. Диктори мали можливість попередньо ознайомитись із фрагментами оповідань, проставити всі необхідні позначки, котрі сприяли б коректному прочитанню текстів. До початку запису кожен диктор декілька разів читав тексти вголос, добираючи найвдалішу, на його думку, форму реалізації запропонованих текстів.

Формування корпусу експериментального матеріалу шляхом дикторського читання художніх текстів дозволяє отримати зразки усного мовлення, які мають ідентичне лексико-граматичне наповнення, але відрізняються просодичним оформленням. Отже, виключається вплив семантико-граматичних факторів на результати експерименту. Отриманий матеріал дає можливість спостерігати специфіку просодичної організації мовлення та вплив окремих вимовних відхилень, зокрема в реалізації ненаголошеного вокалізму, на його супрасегментні характеристики.
Після завершення підготовчого етапу роботи 3 експериментальним матеріалом і проведення запису художніх текстів оповідання в їхньому оригінальному звучанні й начитані дикторами підлягали слуховому аналізу аудиторами-фонетистами зі спеціальною філологічною освітою. Увесь озвучений матеріал був затранскрибований згідно 3 реальним звучанням. Також було виконано членування мовленнєвого потоку на ритмогрупи (далі - РГ), виділено слова, що несуть емфатичний і семантичний наголос. Після зіставлення отриманих даних для проведення інструментального дослідження сформовано вузький корпус експериментального матеріалу, загальною тривалістю звучання 24 хвилини, до якого увійшли фрагменти шести оповідань Вірджинії Вулф.

Усебічне дослідження реалізації систем голосних і приголосних фонем у мовленні зумовлює необхідність залучення як суб'єктивних, так і об'єктивних методів аналізу. Потреба врахування даних слухового, або аудиторського аналізу, який належить до суб'єктивних методів дослідження, не викликає сумнівів, оскільки для комунікації важливо насамперед те, що сприймається, а не те, що фіксується інструментально.

Водночас неприпустимим $\epsilon$ ігнорування об'єктивних акустичних характеристик звуків, отриманих шляхом осцилографічного й сонаграфічного видів аналізу мовлення, позаяк виявлення кореляції між даними фізичного/об' єктивного й перцептивного/суб'єктивного характеру сприяє глибшому проникненню в специфіку слухового сприйняття, завдяки чому дозволяє оптимально розв'язати визначені в дослідженні завдання.

Згідно $з$ наведеними теоретичними положеннями була складена програма для аудитивного аналізу, яка мала такі завдання:

1. Визначення природності звучання експериментального матеріалу, відповідності досліджуваних текстів нормі англійської вимови.

2. Транскрибування та членування текстів на РГ із позначенням наголошених і ненаголошених складів.

3. Відбір лексичних одиниць для акустичного аналізу ненаголошеного вокалізму.

Мета слухового аналізу експериментального матеріалу полягала в здійсненні фахової оцінки просодії озвученого художнього тексту, на основі якої можливо зробити висновки про просодичні ознаки ненаголошеного вокалізму британського варіанту англійської мови. Слуховий аналіз художніх текстів аудиторами-фонетистами передбачав установлення їх перцептивних характеристик, а також відбір матеріалу для проведення акустичного аналізу. 
Слуховий аналіз проводився в такій послідовності:

Матеріал для аналізу. Оскільки художні оповідання, що входять до корпусу експериментального матеріалу, не досить тривалі, аудиторам пропонувалися для прослуховування повні тексти.

Підготовка бланків та інструкцій.

Проведення аудіювання.

Обробка даних аудиторського аналізу, яка передбачала статистичну й лінгвістичну інтерпретацію отриманих результатів експерименту.

Аудитивний аналіз художніх текстів проводився 4 фонетистами, викладачами фонетики англійської мови 3 досвідом виконання експериментально-фонетичних досліджень. Програмою аудитивного аналізу передбачено виконання декількох етапів дослідження.

На першому етапі експерименту аудиторам фонетистам пропонувалися аудіозаписи оповідань британської письменниці Вірджинії Вулф, озвучені носієм мови й прочитані україномовними дикторами 3 різним ступенем володіння англійською мовою. Мета першого етапу полягала в оцінці начитаних дикторами текстів із боку їхньої відповідності стандартній вимовній нормі англійської мови.

Для проведення такого етапу експерименту було обрано метод семантичного диференціала, який вперше запропонував Ч. Осгуд, досліджуючи індивідуальні ставлення слухачів до почутого. Реципієнти оцінювали спосіб презентації тексту певним диктором із позиції особистого враження за запропонованою шкалою (Глухов, 2005: 64). Процедура проведення експерименту полягала в тому, що респонденти, прослуховуючи фрагменти художніх текстів, оцінювали просодичні елементи за семибальними двополярними шкалами, кожна 3 яких представляє градацію певної ознаки. Після прослуховування аудіотексту респондент оцінює спосіб презентації тексту за наведеними нижче ознаками, відзначивши в протоколі цифру, оцінку від -3 до +3 , яка найкраще характеризує ступінь вияву кожної ознаки в запропонованому фрагменті.

Метод семантичного диференціала широко використовується в психолінгвістиці й психосемантиці й дозволяє оцінити асоціативні зв'язки, що виникають у свідомості людини під час сприйняття того чи іншого явища. Методика семантичного диференціала $є$ незамінною під час вивчення психології сприйняття та поведінки людини, а тому часто застосовується в дослідженнях масової комунікації, реклами й цілком виправдана як метод аналізу мовлення.
Використання методу семантичного диференціала для оцінки читання текстів українцями й носіями англійської мови дозволяє виявити різницю в сприйнятті однакових за змістом текстів, що мають різну просодичну організацію. Суттевий вплив просодичного оформлення прочитаних текстів на аудиторів підтверджено результатами аудитивного й акустичного аналізу.

Для здійснення слухового аналізу окрім текстів, озвучених британським диктором, підготовлено шість оповідань, начитаних українцями 3 різним рівнем опанування англійською мовою.

Таким чином, аналізу підлягали п'ять варіантів однакових текстів, порівняння яких дозволило виявити елементи просодії, які впливають на сприйняття та розуміння змісту почутого.

Під час проведення слухового аналізу аудитори прослуховували тексти в довільній послідовності. Після презентації всіх текстів учасники експерименту обирали той із фрагментів, який, на їхню думку, був легшим для сприйняття, та відзначали у формулярі просодичні параметри, що сприяли кращому розумінню обраного тексту. Експерти прослуховували тексти й оцінювали мовлення дикторів за такими параметрами: 1) природність звучання; 2) зрозумілість вимови; 3) відповідність вимовній нормі.

Спираючись на результати експертної оцінки й транскрипції текстів відповідно до їх реального звучання, корпус експериментального матеріалу склали лише ті фрагменти, що: 1) мали не природне звучання; 2) не зрозумілу вимову; 3) не відповідали вимовній нормі англійської мови.

Мета описаного етапу експерименту полягала в розкритті характеру взаємозв'язку між просодичним оформленням озвучених текстів залежно від рівня опанування англійською мовою та їх сприйняттям реципієнтами. Своєю чергою отримані результати дозволяють зробити певні висновки щодо особливостей актуалізації потенціалу просодії мовлення та виявити параметри, які $\epsilon$ найбільш значущими для максимального точного сприйняття текстів слухачами. Основна гіпотеза грунтувалася на припущенні, що тексти, начитані українцями 3 різним рівнем опанування англійською мовою, допоможуть виявити, який із просодичних параметрів усного мовлення впливає на зрозумілість почутого.

На другому етапі під час прослуховування текстів аудитори транскрибували відібрані фрагменти, здійснювали членування текстів на ритмогрупи, позначали наголошені склади у фразах, синтагмах і ритмічних групах, розставляли паузи із зазначенням їхньої тривалості. 
Відповідні позначки проставлялися в роздрукованих текстах запропонованих оповідань. Кількість прослуховувань матеріалу не обмежувалась. Згідно з інструкцією, аудитори-фонетисти затранскрибували мовленнєвий матеріал відповідно до його реального звучання, встановили дистрибуцію фразового наголосу в прочитаних текстах, позначивши межі фонетичних слів; занотували в протоколах орфографічного запису встановлені на рівні сприйняття відхилення від кодифікованої орфоепічної норми.

Під час проведення третього етапу аудитивного аналізу експертам було запропоновано обрати 3 фрагментів (відзначених на першому етапі) слова для подальшого порівняння та аналізу модифікацій акустичних параметрів ненаголошених голосних.

На основі представлених аудиторами даних підраховувалася частота появи різних алофонів голосних фонем у ненаголошеній позиції фонетичного слова в мовленні кожного 3 дикторів. Подальший аналіз отриманих показників алофонічного варіювання фонем показав, що диктори 3 однісї групи виявляють спільні тенденції в реалізації ненаголошених голосних. Таким чином, було підсумовано дані для кожної із 4 груп інформантів.

Результати слухового аналізу експериментального матеріалу дозволяють оцінити перцептивні показники просодії англійського мовлення українців та описати спільні тенденції в реалізації ненаголошених голосних.

Проте аудитивний аналіз як суб'єктивний метод отримання даних $є$ недостатнім для точної характеристики досліджуваних фонетичних явищ та об'єктів, оскільки специфіка сприйняття почутого кожним аудитором допускає певний суб'єктивізм в оцінках, здобутих шляхом перцептивного аналізу матеріалу. 3 метою більш об'єктивного вивчення закономірностей ритмічного оформлення англійського мовлення українців застосовувались інструментальні методи дослідження.

Дані, отримані в результаті аудитивного аналізу англійського мовлення українців, перевірено шляхом обробки експериментального матеріалу за допомогою комп'ютерних програм PRAAT Version 4.4.07, Sound Forge Pro TRIAL Version 10.0 із застосуванням комплексної методики електроакустичних досліджень.

Тембральні характеристики ненаголошених голосних досліджувалися за допомогою сонаграфічного аналізу, який дозволяе встановити основний тон, частоту гармонік (або обертонів) основного тону й відносну інтенсивність частотних складників звука (Глухов, 2005: 20).
Сонографічний аналіз передбачав вивчення формантної структури ненаголошених голосних взаємного розміщення їхніх формант, насамперед F1 i F2, які $\epsilon$ найсуттєвішими для опису якості (тембру) голосних звуків. Як відомо, частоти формант визначаються конфігурацією мовленнєвого тракту, пов'язаною зі специфікою артикуляції (Соколова, 2010: 38). Значення першої форманти F1 корелює зі ступенем підняття голосного в той час, як частота другої форманти F2 залежить від ступеня просунення голосного вперед по горизонталі. Лабіалізація звуку приводить до зменшення частотних значень усіх формант. Таким чином, ненаголошений звук буде мати характеристики центрального звуку середнього ряду.

Унаслідок фізіологічних відмінностей між людьми форманти голосних не мають абсолютно однакових показників навіть у вимовлянні одного й того самого диктора (Глухов, 2005: 90). Так, частотні характеристики F1 i F2 голосних, реалізованих дикторами жіночої статі, перевищують формантні значення F1 і F2 голосних у вимовлянні чоловіків, що можна пояснити наявністю коротшої надставної трубки й тонших голосових зв'язок у жінок. Тому до експериментальних груп нами були відібрані лише диктори жіночої статі.

Для акустичного аналізу ненаголошених звукових сегментів в озвучених художніх текстах передбачалося інструментальне вимірювання та фіксація таких основних акустичних показників ненаголошених голосних, як частота основного тону (ЧОТ, що є частотним складником просодії), тривалість (часова характеристика мовлення) та інтенсивність (динамічна складова частина просодичного оформлення). Це дало змогу схарактеризувати модуляції частотних, динамічних і часових параметрів звукового сигналу, шляхом яких формується просодичне оформлення усного мовлення. Чергування наголошених і ненаголошених складів, зміни тонального діапазону, часова регламентованість ритмоодиниць і зміни сили голосу на окремих фрагментах тексту сприяють реалізації основної функції просодії - створення фонетичної довершеності звучання та забезпечення чіткості сприйняття основного змісту почутого.

Завдання акустичного аналізу полягає у виявленні тих параметрів частотної, часової та динамічної складової частини просодії, які є найбільш значущими для коректного оформлення англійського мовлення українців. Підрахунок значень акустичних параметрів здійснювався окремо для кожного диктора.

Під час дослідження просодичних характеристик озвучених художніх текстів враховувались як 
абсолютні, так і відносні значення, що сприяло усуненню випливу індивідуальних просодичних відмінностей у мовленні дикторів на результати експерименту й отриманню точніших об'єктивних даних. Важливим параметром для виявлення характерних особливостей англійського мовлення українців $є$ формантні характеристики ненаголошених голосних. Вимірювання F1 та F2 дали змогу проаналізувати відмінності в акустичних характеристиках ненаголошеного вокалізму, що приводять до просодичних змін у мовленні.
Висновки. Узагальнюючи викладене, обрані методи експериментально-фонетичного дослідження дають змогу скласти програму проведення експерименту, що дозволить виявити вплив відхилень на сегментному рівні на просодичне оформлення усного мовлення та встановити його зв'язок зі зрозумілістю та природністю звучання англійського мовлення українців. Також буде вивчено акустичні характеристики ненаголошених звуків задля їх порівняння з еталоном і встановлення типових вимовних відхилень.

\section{СПИСОК ВИКОРИСТАНИХ ДЖЕРЕЛ}

1. Арнольд И. В. Стилистика современного английского языка : учебное пособие для студентов педагогических институтов по специальности «Иностранный язык». Москва : Просвещение, 1990. 300 с.

2. Артёмов В. А. Метод структурно-функционального изучения речевой интонации : учебное пособие. Москва : Моск. гос. пед ин-т иностр. языков им. М. Тореза, 1974. 60 с.

3. Ахманова О. С. Словарь лингвистических терминов. Москва : КомКнига, 2005. 576 с.

4. Великая Е. В. Просодия в стилевой дифференциации языка : монография. Москва : «Прометей» МПГУ, 2008. 163 с.

5. Глухов В. П. Основы психолингвистики : учебное пособие для студентов педвузов. Москва : АСТ; Астрель, 2005. $351 \mathrm{c}$.

6. Кантер Л. А. Системный анализ речевой интонации : учебное пособие. Москва : Высш. шк., 1988. 128 с.

7. Калита А. А. Експериментально-фонетичні дослідження: підходи, напрями, аспекти. Науковий вісник кафедри ЮНЕСКО КНЛУ. Випуск 1. Київ : Вид-во КНЛУ, 2000. С. 13-20.

8. Кожина М. Н. Речеведение и функциональная стилистика: вопросы теории. Пермь : Изд-во ПГУ: ПСИ: ПССГК, 2002. $475 \mathrm{c}$.

9. Скребнев Ю. М. Кузнец М. Д. Стилистика английского языка : пособие для студентов педагогических институтов. Ленинград : Государственное учебно-педагогическое издательство Министерства Просвещения РСФСР (Ленинградское отделение), $1960.175 \mathrm{c}$.

10. Соколова М. А. Теоретическая фонетика английского языка. Дубна : Феникс+, 2010. 192 с.

11. Соссюр Ф. де. Труды по языкознанию. Москва : Прогресс, 1977. 695 с.

12. Якобсон Р. Избранные работы. Москва : Прогресс. 1985. 456 с.

13. Crystal D. The Cambridge Encyclopedia of the English Language. Cambridge : Cambridge University Press, 1999. $490 \mathrm{p}$.

14. Rubery M. Play It Again, Sam Weller: New Digital Audiobooks and Old Ways of Reading. Journal of Victorian Culture. January 2008. No. 13(1). P. 58-79.

\section{REFERENCES}

1. Arnold I. V. Stilistika sovremennogo angliiskogo yazyka [Stylistics of modern English]. M.: Education, 1990. 300 p [in Russian].

2. Artyomov V. A. Metod structurno-funkzionalnogo izuchenia intonatsii [Method of structural and functional study of speech intonation]. M.: Mosk. state ped in-t foreign. languages. M. Toreza, 1974. $160 \mathrm{p}$ [in Russian].

3. Akhmanova O. S. Slovar lingvisticheskich terminov [Dictionary of linguistic terms]. M.: KomKniga, 2005. $576 \mathrm{p}$ [in Russian].

4. Velikaya E. V. Prosodia v stilevoi differentsiatsii yazyka [Prosody in the style differentiation of language: Monograph]. M.: "Prometheus" Moscow State Pedagogical University, 2008. 163 p [in Russian].

5. Glukhov V. P. Osnovy psicholingvistiki [Fundamentals of psycholinguistics: textbook. manual for students of pedagogical universities]. M.: AST; Astrel, 2005. $351 \mathrm{p}$ [in Russian].

6. Kanter L. A. Sistema analiza rechevoi intonatsii [System analysis of speech intonation]. M.: Higher. shk., 1988. $128 \mathrm{p}$ [in Russian].

7. Kalita A. A. Eksperementalno-phonetychne doslidgennia: pidhody, napriamy, aspekty [Experimental-phonetic research: approaches, directions, aspects]. Scientific newsletter of the UNESCO Chair of KNLU. Vipusk 1. K.: KNLU View, 2000. P. $13-20$ [in Ukrainian].

8. Kozhina M. H. Rechevedenie I funktsionalnaya stilistika: teoreticheskie voprosy [Speech and functional stylistics: theoretical questions]. Perm: PSU Publishing House: PSI: PSGK, 2002. 475 p.

9. Skrebnev Yu. M. Kuznets M. Stilistika angliiskogo yazyka [Stylistics of the English language]. Leningrad: State educational and pedagogical publishing house of the Ministry of Education of the RSFSR (Leningrad branch), 1960. $175 \mathrm{p}$ [in Russian].

10. Sokolova M. A. Teoreticheskaya fonetica angliiskogo yazyka [Theoretical phonetics of the English language]. Dubna: Phoenix +, 2010. 192 p [in Russian].

11. Saussure F. de. Trudy po yazykoznaniu [Works on Linguistics]. Moscow: Progress, 1977. 695 p [in Russian].

12. Yakobson R. Izbrannye raboty [Selected works]. M.: Progress. 1985. $456 \mathrm{p}$ [in Russian].

13. Crystal D. The Cambridge Encyclopedia of the English Language. Cambridge: Cambridge University Press, 1999. 490 p.

14. Rubery M. Play It Again, Sam Weller: New Digital Audiobooks and Old Ways of Reading. - January 2008, Journal of Victorian Culture 13(1):58-79 pp. 